\title{
Foreign Capital and Economic Performance of Pakistan
}

\author{
Minh Hang Le and Ali Ataullah *
}

\begin{abstract}
This paper reviews the trends of two types of foreign capital inflows, namely foreign aid and foreign private investment, to Pakistan. Like other developing countries, the volume of foreign aid to Pakistan has been decreasing. Meanwhile foreign private investment to Pakistan has increased, though not as sharply as that to other developing Asian countries. The study finds that the impacts of foreign capital, aid and private investment on the economic performance of Pakistan have been insignificant. This paper suggests that these consequences are due to the inadequate development of domestic institutional structure, human capital, and indigenous entrepreneurship.
\end{abstract}

\section{Introduction}

If you want to build a factory, or fix a motorcycle, or set a nation right without getting stuck, then classical, structured, dualistic subjectobject knowledge although necessary, isn't enough. You have to have some feeling for the quality of the work. You have to have a sense of what's good. That's what carries you forward. This sense isn't just something you're born with, although you are born with it. It's also something you can develop. It's not just 'intuition', not just unexplainable 'skill' or 'talent'. It's the direct result of contact with basic reality. ${ }^{1}$

Most of the contemporary economic growth literature emphasises the positive impacts of foreign capital, especially that of foreign private investment, in the process of economic growth. Foreign capital, it is claimed, influences the process of economic growth by filling up the savinginvestment gap, increasing productivity, transferring advanced technology, and so on. These conceived benefits have encouraged the authorities in the developing world to liberalise domestic economies to attract foreign capital. Nevertheless, theories and empirics appear to provide ambiguous evidence regarding the impacts of foreign capital on developing economies; there may

\footnotetext{
* The authors are doctoral students at The Business School and The Department of Economics and Finance at University of Durham, UK, respectively. For correspondence and comments: ali.ataullah@durham.ac.uk

${ }^{1}$ Pirsig (1974, pp.287-88)
} 
be costs associated with foreign capital that may prove to be noxious for developing countries.

Like many other governments, the Government of Pakistan (GOP) has been striving to magnetise foreign capital. However, unlike some other developing countries, Pakistan has not been successful in obtaining substantial and consistent foreign capital inflows. Furthermore, the meagre inflows that the country has received have not been appropriately utilised to enhance the economic performance of Pakistan. This paper is a modest attempt to review trends of foreign capital inflows to Pakistan and compare with those of other developing countries in Asia. This paper also reviews the policy measures that the GOP has undertaken to attract foreign capital and compares these policies with those of other Asian countries. Furthermore, the paper tries to evaluate the impacts of foreign capital inflows on the economic performance of the country. Section 2 highlights the recent trends, determinants and role of foreign capital inflows in developing economies. Sections 3 and 4 present a very brief overview of the Pakistani economy and trends of foreign capital inflows to Pakistan, respectively. Section 5 compares the policies adopted by GOP and by other developing countries in Asia. Section 6 tries to briefly evaluate the impacts of foreign capital inflows to Pakistan. Section 7 concludes the paper.

\section{Foreign Capital Inflows to the Developing World:}

Foreign aid and foreign private investment are two important sources of capital for developing countries. The former could be broadly categorised into grants and low interest rate loans, and the latter into foreign portfolio investment (FPI) and foreign direct investment (FDI). The last three decades have witnessed significant changes in patterns and trends of these foreign capital flows to developing countries. Although all categories of foreign capital have increased considerably, their growth rates are substantially different ${ }^{2}$. Foreign aid to developing countries increased from US\$1.9 billion in 1970 to US\$27.1 billion in 1998. This increase, however, is rather modest when compared with the expansion in FDI and FPI (see Chart 2.1). FDI flows increased from US\$2.2 billion in 1970 to US\$24 billion in 1990, and more than US\$170 billion in 1998. FPI, which was negligible until the early eighties, increased to US\$2.8 billion in 1990 and to US\$15.6 billion in 1998 .

\footnotetext{
${ }^{2}$ Other forms of foreign capital inflows, like commercial loans and workers' remittances, are not considered in this paper.
} 
Chart 2.1: Net Resource Flows to Developing Countries in billion US\$ (1970-1998)

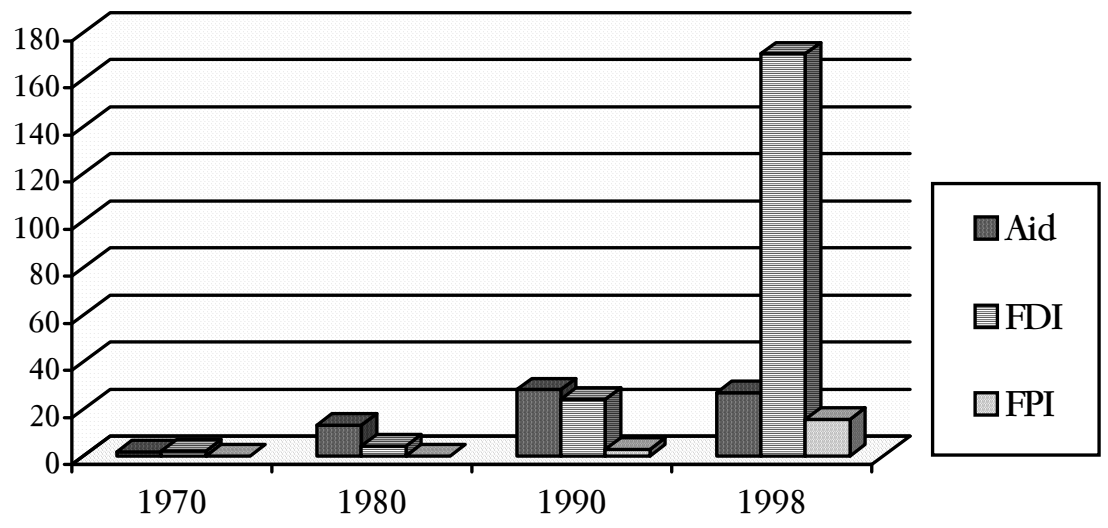

Source: Global Development Finance (2000)

- FDI is net flows of Foreign Direct Investment

- FPI is net flows of Portfolio Equity Flows

- Aid is net flows of Grants (excluding technical cooperation)

\subsection{Foreign Aid}

Foreign aid has been the major source of foreign capital for many developing countries, especially during the 1960s, 1970s, and 1980s. The end of the Cold War, which has diminished the strategic importance of foreign aid and aroused sceptical public opinion about its efficacy, has led to a decline in foreign aid during the 1990s. Although the volume of aid has declined, the number of aid agencies has increased from about 7 in 1960 to about 50 in the 1990s (see Todaro, 1992). The international nongovernmental organisations, such as the World Bank (WB) or the International Monetary Fund (IMF), have assumed eminent authority over the economic policies of developing countries. These agencies usually impose strict conditions on the recipient countries and threaten to withdraw this aid if the conditions are not met.

Foreign aid, to some extent, has helped to promote growth and structural transformation in the recipient countries, particularly at the time of post-war reconstruction and natural disasters. It is, however, widely argued that the impacts of foreign aid on development are rather limited because foreign aid is usually directed towards military and political fields instead of human development. Also, the conditions imposed by aid agencies 
may lead to limitations on policy autonomy. Some studies suggest that foreign aid can play a critical role in economic stabilisation by defusing distributional conflict, while others suggest that aid could lead to a delay in necessary reforms by providing additional resources to vested interests that encourage authorities "to resist adjustments and delay the day of reckoning (Casella and Eichengreen 1996, p.605)" ${ }^{3}$. Empirical evidence suggests that foreign aid has not contributed profoundly to the economic growth and development of recipient countries and it has even increased inequalities among different groups ${ }^{4}$. Moreover, the increasing tendency toward providing loan-type aid instead of grant-type aid and toward tying aid to the exports of donor countries has left many Third World nations with a phenomenal debt burden. Given the equivocal effects of foreign aid and limited control over the quantity of aid received, policy makers in developing countries have started seeking alternative sources of foreign capital i.e. foreign private investment (FDI and FPI).

\subsection{Foreign private investment:}

\section{a) Foreign direct investment:}

FDI, besides filling the saving-investment gap, may bring advanced technologies and new entrepreneurial skills, which enhance production and export composition of host economies. Foreign firms operating in host countries are also expected to diffuse ideas and technology to domestic enterprises that, in turn, will improve domestic management capabilities and the export performance of host countries. It is, therefore, believed that inward FDI accelerates the stagnant growth process of the underdeveloped countries 5 . These inflows of FDI, however, are unevenly distributed among the developing countries. Since the 1970s, more than two thirds of the total FDI inflows have been concentrated in a few countries, many of which have now become middle-income and newly industrialised countries (see Table 2.1). The literature suggests that FDI inflows largely depend on the size and/or growth of the domestic market, labour cost and quality, trade regime, and above all the attitude of host governments toward foreign investment ${ }^{6}$. With the increasing emphasis on the role of FDI in the process of economic growth, the competition among developing countries has become fierce, leading to more open and liberalised policies to attract foreign investors. Between 1991 and 2000, there were 1185 national

\footnotetext{
${ }^{3}$ See Sachs (1994) and Eberstadt (1992) for the positive and negative role of foreign aid.

${ }^{4}$ For details, see Bornschier et al. (1987), Rana and Dowling (1988), and Griffin (1991).

${ }^{5}$ For details, review of the potential benefits of FDI, see World Investment Report (1992).

${ }^{6}$ For the vast literature on the FDI determinants in developing countries see e.g. Root and Ahmed (1979), Lucas (1993) and Loree and Guisinger (1995).
} 
regulatory changes, of which 1121 were aimed to create a more favourable environment for FDI. In 1996, for example, out of 114 new changes in investment regimes introduced by 10 developed and 55 developing countries, 98 were toward liberalisation or the promotion of FDI (see Table 2.2). Generous financial and fiscal incentives have been offered with the hope to attract more investment. It is however not likely that liberalisation and incentives are enough for a country to attract foreign investors ${ }^{7}$.

Table 2.1 - The ten largest recipients of FDI in the developing world (Average annual inflows, Billions of US\$)

\begin{tabular}{|c|c|c|c|c|c|c|c|c|}
\hline & $\begin{array}{c}\text { Host } \\
\text { economie } \\
\mathrm{s} \\
\end{array}$ & $\begin{array}{c}1970 \\
- \\
1979 \\
\end{array}$ & $\begin{array}{c}\text { Host } \\
\text { economies }\end{array}$ & $\begin{array}{c}1980- \\
1990\end{array}$ & $\begin{array}{c}\text { Host } \\
\text { economies }\end{array}$ & $\begin{array}{l}1991- \\
1995^{\mathrm{a}}\end{array}$ & $\begin{array}{c}\text { Host } \\
\text { economie } \\
\mathrm{s} \\
\end{array}$ & $\begin{array}{l}1996- \\
2000^{a}\end{array}$ \\
\hline 1 & Brazil & 1.3 & Singapore & 2.3 & China & 22.5 & China & 41.8 \\
\hline 2 & Mexico & 0.6 & Mexico & 1.9 & Mexico & 6.3 & HongKong & 25.1 \\
\hline 3 & Malaysia & 0.3 & Brazil & 1.8 & Singapore & 4.8 & Brazil & 24.5 \\
\hline 4 & Nigeria & 0.3 & China & 1.7 & Malaysia & 4.5 & Mexico & 12.1 \\
\hline 5 & Singapore & 0.3 & HongKong & 1.1 & Brazil & 2.5 & Argentina & 11.7 \\
\hline 6 & Egypt & 0.3 & Malaysia & 1.1 & Indonesia & 2.3 & Singapore & 8.6 \\
\hline 7 & Indonesia & 0.2 & Egypt & 0.9 & Hungary & 2.2 & Poland & 6.6 \\
\hline 8 & Hong Kong & 0.1 & Argentina & 0.7 & Bermuda & 2.1 & S. Korea & 6.3 \\
\hline 9 & Iran & 0.1 & Thailand & 0.7 & Argentina & 2.0 & Colombia & 5.5 \\
\hline 10 & Uruguay & 0.1 & Taiwan & 0.5 & Thailand & 1.8 & Malaysia & 5.1 \\
\hline & $\begin{array}{c}\text { Share of } \\
\text { flows to } \\
\text { developing } \\
\text { countries } \\
(\%)\end{array}$ & 66 & $\begin{array}{c}\text { Share of } \\
\text { flows to } \\
\text { developing } \\
\text { countries } \\
(\%)\end{array}$ & 68 & $\begin{array}{c}\text { Share of } \\
\text { flows to } \\
\text { developing } \\
\text { countries } \\
(\%) \\
\end{array}$ & 73 & $\begin{array}{c}\text { Share of } \\
\text { flows to } \\
\text { developing } \\
\text { countries } \\
(\%)\end{array}$ & 74 \\
\hline
\end{tabular}

Sources: World Investment Report (various issues)

${ }^{a}$ Calculated by the authors

\footnotetext{
${ }^{7}$ For an extensive discussion about the effects of incentives and other policies on the FDI inflows see Oman (2000)
} 
Table 2.2 - National Regulatory Changes, 1991-2000

\begin{tabular}{|c|c|c|c|c|c|c|c|c|c|c|}
\hline Item & 1991 & 1992 & 1993 & 1994 & 1995 & 1996 & 1997 & 1998 & 1999 & 2000 \\
\hline $\begin{array}{l}\text { Number of } \\
\text { countries } \\
\text { that } \\
\text { introduced } \\
\text { changes in } \\
\text { their } \\
\text { investment } \\
\text { regimes a }\end{array}$ & 35 & 43 & 57 & 49 & 64 & $65^{\mathrm{b}}$ & 76 & 60 & 63 & 69 \\
\hline $\begin{array}{l}\text { Number of } \\
\text { regulatory } \\
\text { changes of } \\
\text { which: }\end{array}$ & 82 & 79 & 102 & 110 & 112 & 114 & 151 & 145 & 140 & 150 \\
\hline $\begin{array}{l}\text { More } \\
\text { favourable } \\
\text { to } \mathrm{FDI}^{\mathrm{c}}\end{array}$ & 80 & 79 & 101 & 108 & 106 & 98 & 135 & 136 & 131 & 147 \\
\hline $\begin{array}{l}\text { Less } \\
\text { favourable } \\
\text { to FDI } \\
\end{array}$ & 2 & - & 1 & 2 & 6 & 16 & 16 & 9 & 9 & 3 \\
\hline
\end{tabular}

Sources: World Investment Report 2001

${ }^{a}$ Including developed and developing countries

${ }^{\mathrm{b}} 10$ developed and 55 developing countries

${ }^{\mathrm{c}}$ Including measures aimed at strengthening market supervision, as well as incentives

${ }^{\mathrm{d}}$ Including measures aimed at reducing incentives

Despite their efforts, only a few developing countries have succeeded in attracting FDI, and there is little evidence that this FDI has fostered growth and development in these countries. This is because transnational companies (TNCs) might just exploit natural resources, cheap labour and lax regulations in host countries, and crowd out indigenous entrepreneurs. Some cross-country comparative analyses show no systematic evidence regarding the link between growth and $\mathrm{FDI}^{8}$. The contemporary empirical studies insinuate that there are some prerequisites, such as a threshold level

\footnotetext{
${ }^{8}$ See e.g. Blomstrom and Kokko (1996) and Saggi (2000).
} 
of human capital endowment and an outward-oriented strategy, which host countries must possess in order to gain from $\mathrm{FDI}^{9,10}$.

\section{b) Foreign portfolio investment (FPI):}

The financial liberalisation programmes adopted by developing countries from the early 1980s onward have played a key role in attracting a huge amount of FPI inflows. These liberalisation policies followed the creation of new financial markets and institutions, and the emergence of new financial instruments and regulation. These policy measures helped in attracting a huge influx of FPI and the emerging stock market capitalisation grew more than tenfold between 1986-1995, which is claimed to be mainly due to the trend of institutionalisation of savings and investments in developed countries and liberalisation of financial markets in developing countries (see, World Investment Report, 1997). According to the International Financial Corporation, in 1988 only three countries were categorised as free [from barriers] for foreign investors to invest in stocks listed locally. But, in 1995, twenty-six were classified as free, eleven were relatively free and only one was classified as closed for foreign investment (World Investment Report, 1997). It is claimed that FPI contributes to the financing of local firms in the primary and secondary market ${ }^{11}$ by increasing the liquidity of local security markets and strengthening the local financial infrastructure. These developments may also facilitate the operations of TNCs, which, in turn, could help the country attract more FDI. FPI flows are dependent on the development of local stock markets, degree of market liquidity, and the level of regulation regarding information disclosure and accounting standards.

FPI may also entail negative consequences for the developing countries. First, FPI inflows are usually more unstable and volatile than FDI because the former does not involve long-term commitment by foreign investors and investors can easily pull out of the developing countries when their "animal spirits" are low. For example, the recent Asian financial crisis

\footnotetext{
${ }^{9}$ See Blomstrom et al. (1994); Borenzstein et al. (1998); and Balasubmaranyam et al. (1999).

${ }^{10}$ The surge of FDI flows in the form of Merger and Acquisition (M\&A) to East Asian countries, which have been severely affected by the 1997 crisis, has raised further doubts on the benefits of FDI. This form of FDI is criticised for its possible adverse effects on economic development as it may hamper domestic industries (see, Zhan and Ozawa, 2001). Hausmann and Fernandez-Arias (2000) even argues that the rise of FDI flow is an indication that markets are working poorly, institutions are inadequate and risks are high. However this study covers the data of a very recent period, i.e. 1996-1998 and mainly for Latin American countries, thus the long-run implications for FDI flows to developing countries seem limited.

${ }^{11}$ See, for example, WIDER (1990) for potential positive impacts of foreign portfolio investment.
} 
shows how easily capital can fly away from a country and it also shows quite clearly the troubles that FPI may bring to the host countries. It is widely argued that the recent Asian financial crisis is partly due to the problem of speculation, moral hazard and asymmetric information in inappropriately structured domestic financial markets (see, for example, Mishkin, 1999). Secondly, building on the post-Keynesian framework, Grabel (1996) suggests that foreign portfolio investment has two negative, mutually reinforcing effects: 1) exacerbation of constraints on policy autonomy, and 2) increased vulnerability of the economy to risk, financial volatility, and crisis.

To sum up, foreign private investment could play a vital role in the economic growth of developing countries, provided that governments play an active role in attracting and accelerating the benefits of foreign investment. The authorities not only need to pursue policies to attract foreign private investment, they must initially create a sound environment to gain from such investment. Policies may range extensively from offering financial and fiscal incentives to improving the institutional and legal framework and investing in infrastructure and human resources to meet the requirements of foreign investors as well as to distribute the benefits of foreign investment to the overall society.

\section{Pakistan's Economy}

During the last five decades, Pakistan has witnessed a vivid change in its economic structure ${ }^{12}$. The share of the agriculture sector, the emblem of Pakistan, in Gross Domestic Product (GDP) has decreased from 60\% in 1950 to $26.3 \%$ in 1998 . Gross domestic investment (GDI) per GDP has increased three-fold from $5 \%$ in 1950 to $17.1 \%$ in 1998 . In 1950 there were no manufacturing products in merchandise exports, but in 1998 they accounted for $84 \%$. Share of agriculture value added in GDP has dropped significantly from $46 \%$ in 1960 to $26 \%$ in 1998 , while that of industry and services has increased from $15 \%$ and $38 \%$ to $24 \%$ and $48 \%$, respectively. Regardless of these structural changes, agriculture still plays an important role in the Pakistani economy. Value added is highest in agro-industries i.e. industries that have linkages to agriculture. The small-scale industrial sector, although often neglected by the government, has been the mainstay of Pakistan's economy. The public sector, which is usually criticised for being inefficient, constitutes a major portion of industrial production and provides a major source of employment ${ }^{13}$. Industrial diversification is still poor with too much concentration in some industries - textiles, for instance. The share of

\footnotetext{
${ }^{12}$ For an excellent overview of the Pakistani economy, see Husain (1999) and Zaidi (1999).

${ }^{13}$ See, Zaidi (1999, chapters 6, 7 and 8) for a comprehensive review of the process of industrialisation in Pakistan and role and efficiency of the Public sector.
} 
manufacturing in industry is still low and its technological level, represented by the share of manufacturing added value in GDP, has only increased by a few percents after nearly 50 years (see Chart 3.1).

Chart 3.1 Sectoral value added as percentage of GDP

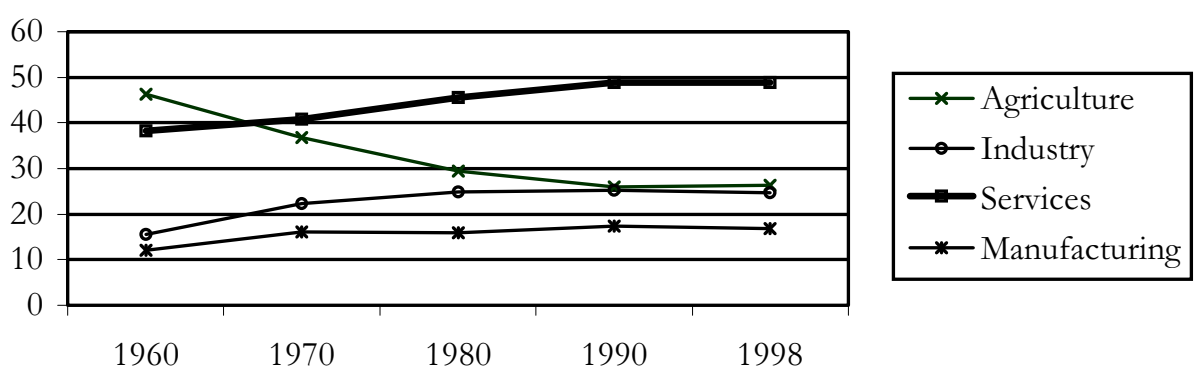

Source: World Development Indicators 2001

Initially, the main source of foreign capital for Pakistan was official foreign aid, which still overshadows foreign private investment. Foreign private investment was not widely encouraged until the issuance of the Foreign Private Investment Act 1976. Despite the government's attempts, the amount of foreign private investment inflows to Pakistan is meagre compared with that to other developing countries.

\section{Foreign Capital Inflows to Pakistan}

\subsection{Foreign aid to Pakistan}

Foreign aid has always been an important source of capital for Pakistan, especially during the 1960s and 1970s (see, for example, Papanek, 1967). During this period, Pakistan was one of the largest aid recipients in Asia (see Table 4.1). In the 1980s, Pakistan would again receive large foreign aid flows due to its front-line role in the American-Russian conflict over Afghanistan. These aid inflows, which reached US $\$ 2$ billion annually by the mid-1980s, are claimed to have supplemented meagre domestic savings and foreign remittances, and enhanced the credit worthiness of Pakistan (see Husain, 1999). Nonetheless, foreign aid flows to Pakistan have also been moving in paralle1 with the world trend. It has been decreasing over time and moving towards loan-type aid. According to Pakistan Economic Surveys (various issues), the share of grant-type aid in total aid commitment reduced sharply from $80 \%$ in the $1^{\text {st }}$ Plan to $12 \%$ in $1970-1978$ and to less than $9 \%$ since 1993 . Also, the aid agencies, such as IMF and WB, have become more influential in dictating the GOP. In section 6.1, we will try to evaluate the impact of this foreign aid on the process of economic development in Pakistan. 
10 The Lahore Journal of Economics, Vol.7, No.1

Table 4.1 Foreign aid to Pakistan and selected Asian countries

\begin{tabular}{|c|c|c|c|c|}
\hline & \multicolumn{2}{|c|}{ Aid per GNP } & \multicolumn{2}{|c|}{$\begin{array}{c}\text { Aid per capita (current } \\
\text { US\$) }\end{array}$} \\
\hline & 1960 & 1970 & 1960 & 1970 \\
\hline Pakistan & 6.8 & 4.2 & 5.5 & 7 \\
\hline Bangladesh & $\mathrm{N} / \mathrm{A}^{\mathrm{a}}$ & N/A & N/A & N/A \\
\hline India & 2.3 & 1.3 & 1.6 & 1.5 \\
\hline Indonesia & N/A & 4.7 & 0.9 & 4 \\
\hline Mauritius & 0.3 & 2.7 & 0.7 & 7.3 \\
\hline Nepal & 1.6 & 2.7 & 0.9 & 2.1 \\
\hline Philippines & 0.7 & 0.7 & 1.8 & 1.2 \\
\hline Malaysia & 0.6 & 0.6 & 1.6 & 2.4 \\
\hline Korea, Rep. & 6.3 & 3.0 & 10 & 8.6 \\
\hline Hong Kong & 0.4 & 0.03 & 1.9 & 0.4 \\
\hline Singapore & -0.04 & 1.5 & -0.2 & 15 \\
\hline Sri Lanka & 0.7 & 2.1 & 1.1 & 3.9 \\
\hline Thailand & 1.5 & 1.04 & 1.6 & 2 \\
\hline
\end{tabular}

Source: World Development Indicators 2001

${ }^{\text {a }}$ Not available

\subsection{FDI to Pakistan:}

\section{Trends of FDI inflows to Pakistan}

Increase in FDI to Pakistan during the last two decades, though not as sharp as in the other developing countries as a whole or in East Asia, justifies the assertion supra that foreign private investment may be a substitute for the aid flows (Chart 4.1). Like other developing countries, the main determinants of FDI flows to Pakistan are domestic market size, availability of cheap labour (skilled and un-skilled), macroeconomic stability, and the structural reform process ${ }^{14}$.

The history of FDI inflows to Pakistan can be broadly divided in two phases. The first phase is characterised by the attempt of the government to attract foreign direct investment through the Foreign Private Investment Act 1976. Before this Act, private foreign investment was regulated by the government's statement of industrial policy issued in 1959. The 1976 Act provided security against expropriation and assured adequate compensation in case of acquisition. It also guaranteed the remittance of profit, capital, and up to $50 \%$ of net income. Priority was given to projects that were

\footnotetext{
${ }^{14}$ For determinants of FDI in Pakistan, see Buckley (2000), Khan (1996), or Akhtar (2000).
} 
capital-intensive, technologically advanced, or supposed to strengthen the Balance of Payments position. Several channels, like the One Window facility and the establishment of the Board of Investment, were brought to light to promote the inflows of FDI.

\section{Chart 4.1 Foreign aid and FDI as percentage of GDI (1970-1998)}

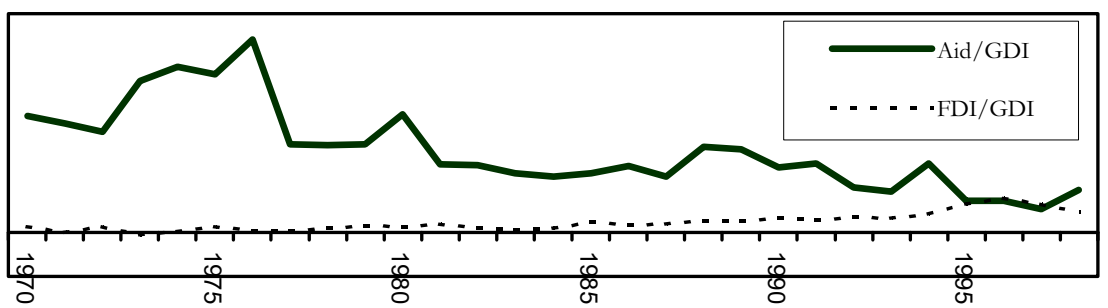

Source: World Development Indicators 2001

As discussed in section 2.2, the incentives provided by host governments are not a mere decisive determinant to stimulate foreign direct investments in developing countries; therefore, the effects of incentives provided by the GOP alone were not overwhelming enough to make Pakistan an optimal destination for FDI. Chart 4.2 suggests that from 1970 until the mid-1980s, the annual inflow of FDI was still modest. The low level of FDI inflows could be attributed to political instability, threats due to Bhutto's nationalisation process, and the lack of the government's commitment to improve physical infrastructure and human capital. During this period, some other East Asian economies like Hong Kong and Singapore, proved to be relatively more successful in improving the domestic economic infrastructure and, therefore, were able to attract a number of foreign investors.

\section{Chart 4.2 FDI inflows to Pakistan at current million US\$ (1970-2001)}

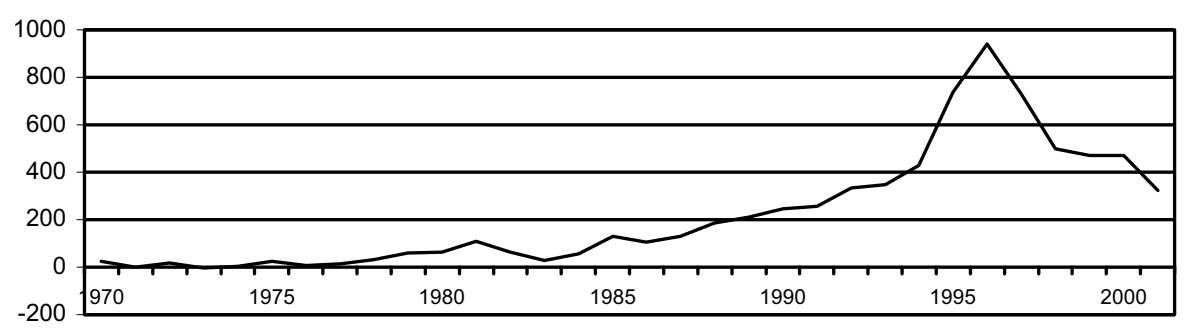

Source: Data from 1970-1998 is from World Development Indicators, 2001; Data from 1999-2001 is from State Bank of Pakistan Annual Report, 2001. 
The second phase started in the late 1980s with the abolition of controls on capital flows, income remittances and transfer, and ownership. Tax holidays and tariff concessions were granted to foreign investors. The post1988 period is characterised by the process of liberalisation and privatisation (see Husain, 1999), which is claimed to have helped accelerating the inflow of foreign investment from US\$185.6 million in 1988 to US\$939 million in 1996. These FDI inflows then dropped to US\$500 million in 1998. On the domestic front, the decline in FDI after 1996 could be attributed to a number of problems like economic sanctions after the nuclear tests, freezing of foreign currency accounts, the Independent Power Producers (IPPs) controversy, and so on. On the external front, the decreasing trend was exacerbated by deterioration in foreign investors' confidence due to the Asian crisis. To restore foreign investors' confidence, a number of policy measures, such as the New Investment Policy 1997 and the Corrupt Business Practices Ordinance 1998, have been implemented.

The post-1988 period not only offers incentives to investors but also represents a shift in the government's focus: agriculture and services are among the new sectors open to foreign investors. During 1997-98, policy documents highlighted the objective level of at least US\$2 billion per year of foreign investment (see, Pakistan Economic Survey, 1997-1998) to expand the industrial base to value-added, export-oriented, hi-tech and agro-based industries. These targets, however, have not been met. On a positive note, the government has been able to resolve the HUBCO issue almost completely, but it may take some time to restore investors' shaken confidence due to this prolonged scandal. The problem may be worsened due to the event of September 11, but it is expected that western aid and debt rescheduling due to Pakistan's role in the so-called "war against terrorism" may, in the long run, help to attract foreign investors. However, due to the possibility of expansion in the American war against terrorism to other countries, particularly Iran, TNCs [may] find it highly risky to engage in long-term commitments in Pakistan. According to the Mid year summary of the Ministry of Finance, the FDI position slightly improved as it stands at US\$205.1 million in 2001 (Ju1Dec) as against US\$142.1 million in the same period in 2000 .

\section{Which industries receive FDI?}

Table 4.2 presents the percentage share of industries receiving FDI during 1996 and 2001. It is interesting to note that, despite the GOP's efforts to increase FDI in export-oriented industries, the industries that exploit natural resources and target the domestic market have received the highest FDI. The power sector, which received around one third of the total FDI inflows until 1998-1999, received only $10 \%$ of the total FDI in 2000-2001 due to saturation 
and the HUBCO conflict ${ }^{15}$. Investment flows to food, beverages and tobacco resumed again after reaching a low level in 1997. Mining and quarrying, especially oil exploration has increased significantly. The share of other industries remained almost unchanged in the 1990s. The textile industry, which is the backbone of Pakistan's exports and which is significantly competitive in international markets, has not been able to attract considerable foreign investment. Other industries - which require a skilled or semi-skilled labour force and are crucial to upgrade the industrial technological level and enhance exports such as electronics, electrical machinery and petrochemicals receive less than $5 \%$ of total foreign investment. The share of foreign investment in services, such as trading and financial business, is also insignificant. The opening up of the stock market to foreign investors and the launching of the Pakistan Fund in the early 1990s has attracted several projects in securities market institutions, credit rating agencies and investment banks. However, the investment in financial business decreased sharply after 1997 and in 2000-2001 there was even a large divestment flow, which accounted for one-fifth of the total flows that year. Overall, despite various policy measures infra, Pakistan's performance in attracting FDI in services, export-enhancing, technology-upgrading, and labour-intensive industries to create jobs for the increasing population, has been quite unimpressive.

Table 4.2 Selected indicators for FDI shares by sector

\begin{tabular}{lrrrrr}
\hline & $\mathbf{1 9 9 6 - 7}$ & $\mathbf{1 9 9 7 - 8}$ & $\mathbf{1 9 9 8 - 9}$ & $\mathbf{1 9 9 9 - 0}$ & $\mathbf{2 0 0 0 - 1}$ \\
\hline $\begin{array}{l}\text { Power } \\
\text { Mining \& quarrying - oil }\end{array}$ & $35.9 \%$ & $39.8 \%$ & $27.8 \%$ & $14.3 \%$ & $9.9 \%$ \\
exp. & & $16.5 \%$ & $23.9 \%$ & $17.0 \%$ & $26.7 \%$ \\
$\begin{array}{l}\text { Food, beverages \& } \\
\text { tobacco }\end{array}$ & $7.6 \%$ & $3.2 \%$ & $1.6 \%$ & $10.6 \%$ & $22.2 \%$ \\
$\begin{array}{l}\text { Textiles } \\
\text { Transport, Storage \& }\end{array}$ & $1.8 \%$ & $4.5 \%$ & $0.4 \%$ & $0.9 \%$ & $1.9 \%$ \\
$\begin{array}{l}\text { Com. } \\
\text { Machinery other than }\end{array}$ & $0.9 \%$ & $1.7 \%$ & $7.1 \%$ & $6.6 \%$ & $25.6 \%$ \\
electrical & $0.3 \%$ & $0.0 \%$ & $0.2 \%$ & $0.7 \%$ & $0.1 \%$ \\
$\begin{array}{l}\text { Electronics } \\
\text { Electrical machinery }\end{array}$ & $0.0 \%$ & $0.4 \%$ & $0.3 \%$ & $0.5 \%$ & $1.1 \%$ \\
$\begin{array}{l}\text { Financial business } \\
\text { Trade }\end{array}$ & $0.6 \%$ & $1.4 \%$ & $0.4 \%$ & $0.3 \%$ & $0.5 \%$ \\
Petrochemicals \& refining & $0.0 \%$ & $3.4 \%$ & $5.2 \%$ & $6.3 \%$ & $-20.4 \%$ \\
\hline
\end{tabular}

Source: Investment indicators - Board of Investment, Pakistan

\footnotetext{
${ }^{15}$ See Pakistan Economic Survey (2000)
} 
14 The Lahore Journal of Economics, Vol.7, No.1

\section{Comparison with other developing countries in Asia}

Pakistan's performance is even more unimpressive when we compare its FDI inflows with that of other developing countries. Table 4.3 shows that in 1999, the average stock of inward FDI as a percentage of GDP in developing countries is $28 \%$ while that of Pakistan is only $17 \%$. The inward FDI stock of Pakistan is much lower than those of East Asian countries, like Singapore and Malaysia. It could be argued that these East Asian economies have a long history of opening and hosting FDI. But the recent FDI inflows in Pakistan are also lower than that of newly opened economies, such as China and Vietnam. In South Asia, though Pakistan has a higher ratio of FDI inward stock per GDP than India and Bangladesh, it is lower than that of Sri Lanka, which started promoting FDI nearly at the same time as Pakistan. In terms of annual inflows, since the early 1990s India has attracted far more FDI than Pakistan or any other countries in the region (see Chart 4.3). This is, to some extent, related to government policies, which will be discussed in the next section. 
Table 4.3 FDI inward stock by host region and economy (in million US\$ and as percentage of GDP)

\begin{tabular}{|c|c|c|c|c|c|}
\hline $\begin{array}{c}\text { Host } \\
\text { region/Year }\end{array}$ & 1980 & 1985 & 1990 & 1995 & 1999 \\
\hline Developing & 240 & 347 & 487694 & 849376 & 1740377 \\
\hline \multirow[t]{2}{*}{ countries } & 837 & 237 & 13.4 & 15.6 & 28.0 \\
\hline & 10.2 & 14.1 & & & \\
\hline \multirow[t]{2}{*}{ Pakistan } & 688 & 1079 & 1928 & 5552 & 10303 \\
\hline & 2.9 & 3.5 & 4.8 & 9.1 & 17.2 \\
\hline \multirow[t]{2}{*}{ Bangladesh } & 63 & 112 & 147 & 180 & 703 \\
\hline & 0.4 & 0.5 & 0.5 & 0.5 & 1.5 \\
\hline \multirow[t]{2}{*}{ India } & 1177 & 1075 & 1667 & 5684 & 16656 \\
\hline & 0.7 & 0.5 & 0.6 & 1.7 & 3.6 \\
\hline \multirow[t]{2}{*}{ Sri Lanka } & 231 & 517 & 681 & 1297 & 2248 \\
\hline & 5.7 & 8.7 & 8.5 & 10.0 & 14.2 \\
\hline \multirow[t]{2}{*}{ China } & 6251 & 10499 & 24762 & 137435 & 305922 \\
\hline & 3.1 & 3.4 & 7.0 & 19.6 & 30.9 \\
\hline \multirow[t]{2}{*}{ Indonesia } & 10274 & 24971 & 38883 & 50601 & 65188 \\
\hline & 14.2 & 28.6 & 34.0 & 25.0 & 46.2 \\
\hline \multirow[t]{2}{*}{ Malaysia } & 5169 & 7388 & 10318 & 28732 & 48773 \\
\hline & 21.1 & 23.7 & 24.1 & 32.9 & 65.3 \\
\hline \multirow[t]{2}{*}{ Singapore } & 6203 & 13016 & 28565 & 59582 & 82859 \\
\hline & 52.9 & 73.6 & 76.3 & 70.0 & 97.5 \\
\hline \multirow{2}{*}{ Thailand } & 981 & 1999 & 8209 & 17452 & 21717 \\
\hline & 3.0 & 5.1 & 9.6 & 10.4 & 17.5 \\
\hline \multirow[t]{2}{*}{ Vietnam } & 7 & 38 & 230 & 6286 & 15875 \\
\hline & 0.2 & 0.6 & 3.6 & 31.1 & 55.6 \\
\hline
\end{tabular}

Source: World Investment Report 2001 


\section{Chart 4.3 FDI inflows to South Asia \\ (1970-1998)}

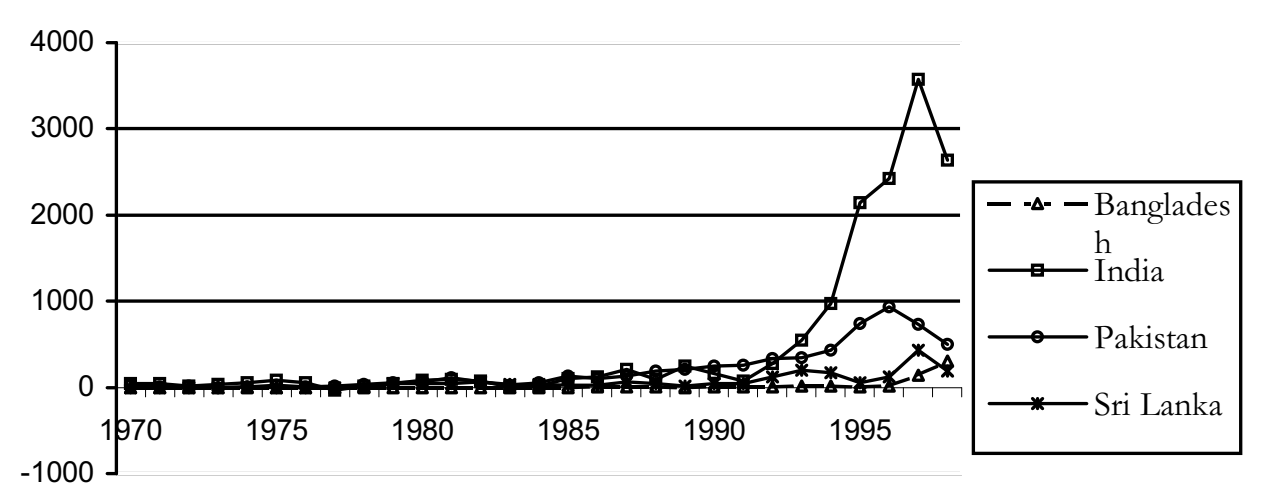

Source: World Development Indicators 2001

\subsection{FPI to Pakistan}

Like other developing countries, FPI is a relatively recent phenomenon in Pakistan $^{16}$. Initially Pakistan participated in external financial markets by offering instruments like foreign exchange bearer certificates issued by the Federal Government, Sovereign Bonds, and dollar bearer certificates (see, Khan, 1996). Later on, the government started opening up the domestic financial market to attract foreign investors. FPI increased significantly after the government opened the entry as well as the exit (expatriation) for foreign investment in the financial market in the early 1990s. The development of the securities market in the $1990 \mathrm{~s}$ includes the establishment of the Central Depository Company, credit rating agencies, corporate brokerage houses, some of which were partially funded by the International Financial Corporation (IFC), coupled with the updated Company Law and Securities and Exchange Law.

Foreign portfolio investment inflows have jumped to a peak level of more than US $\$ 1000$ million in $1994^{17}$, more than double the inflow of FDI in the same year. This flow of capital however has proved to be highly volatile, especially after the Asian financial crisis (Chart 4.4). Some studies suggest that FPI is highly volatile in Pakistan “... since portfolio investment

\footnotetext{
16 The lack of consistent and comparable data prevents a more thorough analytical comparison of FPI to Pakistan and to other Asian countries.

${ }^{17}$ However, Khan (1996) suggests that "this impressive increase does not reflect the true picture of the trends in portfolio investment" because of US\$ 862 million sale of PTC vouchers "which was a one time phenomenon".
} 
in Pakistan is directed mainly toward short-term and some medium-term public debt instruments and the stock exchanges, while access to capital markets through the use of external instruments has been limited" (Khan, 1996, p.864). According to the mid-year review of the Ministry of Finance, FPI has witnessed an outflow of US\$57.1 million during 2001 (Ju1-Dec) as against an outflow of US\$67.4 million in the same period of the preceding year.

\section{Chart 4.4 FPI in the 1990s (million US\$)}

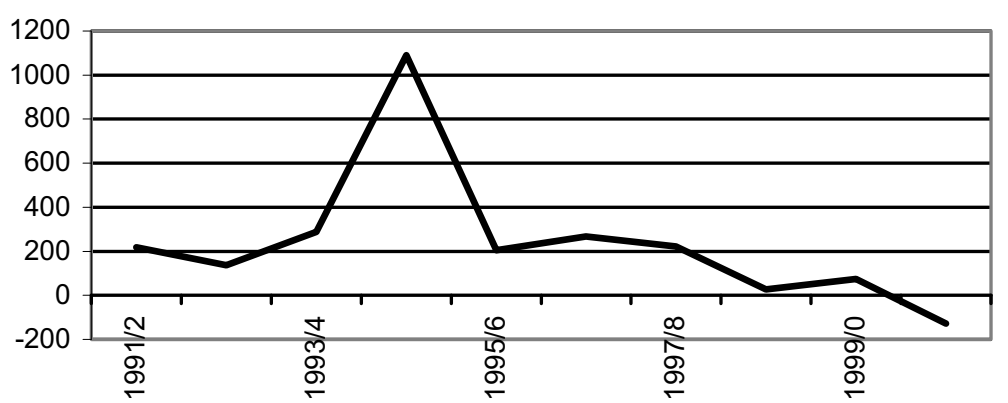

Source: Pakistan Economic Survey (various issues)

\section{Policies toward Foreign Capital Inflows}

Given that the developing countries have little control on foreign aid inflows, this section attempts to review the policies pursued by the GOP toward foreign private investment, particularly toward FDI. Comparisons with the macroeconomic policies adopted by the governments of several other Asian countries provide some insights into why the amount of foreign capital inflows to Pakistan has been relatively meagre.

The huge inflows of foreign private investments in Southeast Asian countries, such as Singapore and Malaysia, are usually attributed to the macroeconomic policies pursued by the authorities in these countries ${ }^{18}$. The governments of Singapore and Malaysia in the mid 1960s and the early 1970s, respectively, were among the earliest in the developing world that adopted the export-oriented strategy and opened the economy to foreign investors. Both countries received massive FDI inflows, especially in electronics and electrical industries, and became leading exporters of these products. In the mid-1980s, the favourable external environment created by the appreciation of the Japanese Yen and the surge in international production of TNCs brought new

\footnotetext{
${ }^{18}$ See Chia (1999)
} 
opportunities as well as challenges. Some latecomer Southeast Asian countries such as Indonesia and Thailand introduced extensive liberalisation, FDI-led and export-led strategies and became competitors of Singapore, Malaysia and other Newly Industrialised Economies (NIEs) in providing cheaper unskilled labour. In 1986 the Indonesian government started deregulating FDI and encouraged investment by small and medium-enterprises in the electronic industry. At the same time the Thai government introduced policies to promote exports and export-oriented foreign investment. Moreover, both countries embarked on a series of macroeconomic reforms and adjustments such as a general programme of reduced protection, improvements in the duty-exemption scheme for imported inputs used in export production in Indonesia, policies toward a more balanced structure of protection, a structural shift in the public sector finances and industrial policies in Thailand. Meanwhile Singapore and Malaysia were facing increasing labour cost, labour shortages and infrastructure inadequacy. To tackle such problems the two governments launched new policies, which were different from the previous period, to promote high-technology, high value-added and skill-intensive investment. The post-1986 period of the Singaporean and Malaysian economies was marked by efforts to enhance the business environment, invest in infrastructure and, more importantly, to develop human capital. Ever since, the development of manpower and local suppliers have been stressed as key issues for sustainable development in these countries.

The policies toward foreign investment pursued by the GOP, in contrast, have been inconsistent and rather rigid. Although the Investment Act was issued in 1976, no further serious policies were adopted to improve the human resources, infrastructure and business environment, which are essential determinants of FDI inflows. The provision of generous financial incentives to foreign investors has been overstressed. Very little attention has been paid to the legal system in Pakistan to efficiently handle the problems faced by foreign investors. The prolonged controversy of the Independent Power Projects (IPPs) is the classic example. Despite having a large and low-cost labour force, and being specialised in the textile industry, Pakistan has failed to attract foreign investment in this sector. Meanwhile, Sri Lanka successfully attracted foreign investment in textile and garments although this country opened the economy in 1977, i.e. one year after Pakistan’s 1976 Investment Act was issued.

Although the post-1988 liberalisation policies have been claimed as successful in attracting huge foreign private investment to Pakistan in the 1990 s, it should be noted that this is the period when the international production of TNCs flourished (see Chart 2.1) and the flows of foreign investment to most of the developing countries increased substantially. The 
speed and amount of FDI inflows to Pakistan in fact is not as high as that to many other developing countries that concentrated more on strengthening domestic human and physical infrastructures. During the 1990s, although both the Sharif and Bhutto governments followed liberalisation policies, they were highly inconsistent with their approaches ${ }^{19}$ and were not able to signal the willingness of the government to protect the interests of foreign investors. It can be argued that by failing to update its macroeconomic policies, especially toward investment in the mid-1980s, Pakistan has lost a golden chance to promote foreign investment.

While the 1990s are marked by the government emphasis on hightechnology and skill-intensive over and against low-skill manufacturing, Pakistan has done far from enough to be able to compete in the more fierce competition for foreign investment. It might not be necessary to mention the experience of Southeast Asian countries, which have taken actions as early as in the 1960s, but it might be interesting to know that India and Sri Lanka have also started progressing. These countries have embarked on the two most fundamental issues in accelerating economic growth through foreign investment: buman capital and linkages between foreign and domestic firms ${ }^{20}$. In terms of human capital, India has the world's third-largest pool of scientific and technical personnel (The US State Department Country Commercial Guides, 2001); and Sri Lanka's illiteracy rate in 1998 was only 8.9\%, compared with 59\% in Pakistan (World Development Indicators, 2001).

In India, a government initiative has been implemented through the UNIDO Partnership Programme since 1999. ${ }^{21}$ The programme is jointly implemented by UNIDO, the government of India, selected TNCs and other large corporations, research institutions, and civil society organisations, to form strong linkages between foreign affiliates and domestic suppliers in the automotive industry. This programme targets SMEs that are second and third-tier suppliers in the industry to create a pool of competent and internationally competitive domestic automotive components suppliers in India. Training is a major component of the programme, including enterprise-oriented shop-floor training in world-class manufacturing methods and training of junior engineers, technical and managerial staff. Software for financial planning and business performance assessment is also provided by UNIDO. A UNIDO survey of participating companies revealed significant improvements in productivity. Sri Lanka has also recognised its constraints in receiving FDI in technology and skills-intensive industries such as lack of

\footnotetext{
${ }^{19}$ Some refer to it as a "muddle-through" scenario (Husain, 1999).

${ }^{20}$ See World Investment Report (2001) for an extensive review of linkage programmes and their potential impacts.

${ }^{21}$ See World Investment Report (2001)
} 
technical manpower and especially reliable local suppliers since the early 1990s. Policy measures have been introduced to create linkages between local suppliers and foreign firms such as promoting local small and medium enterprises (SMEs) to be suppliers for foreign firms ${ }^{22}$.

This brief overview of policy measures undertaken by Pakistan suggests that, in contrast with some other Asian countries, the GOP has not pursued concrete and consistent policies to attract foreign private investment. Too much stress has been given to financial and fiscal incentives, while the importance of macroeconomic infrastructure, human capital, domestic enterprises development and linkages between foreign and domestic firms, has been undermined. Although the policy documents stress the development of institutions, little has materialised in this regard. The experience of other developing countries shows that dynamism and flexibility of the government policies is of paramount importance in accelerating inflows of foreign private investment.

\section{Impact of Foreign Capital on Pakistan's Economy}

'How far can you bear me?', I said to Gwaihir. 'Many leagues', said he, 'but not to the ends of the earth. I was sent to bear tidings not burdens.' 'Then I must have a steed on land', I said, 'and a steed surpassingly swift, for I have never had such need for haste before. ${ }^{, 23}$

To evaluate the impacts of the three types of foreign capital inflows supra on a developing country, it is imperative to understand the overall development strategy of that country. In the case of Pakistan, the development strategy pursued by the GOP is not clear. Each government adopted policies that were inconsistent with that of its predecessor. These inconsistencies in policies have not only signalled the GOP's lack of commitment in protecting the interest of foreign investors, but also have undermined the benefits that could be attained from foreign capital inflows. Given the lack of reliable data, this section briefly highlights the impacts of these foreign capital inflows on the economic performance of Pakistan.

\section{Foreign Aid}

As discussed in section 4.1, during the 1960s, 70s, and 80s Pakistan was among the largest aid recipient countries. But, as most of us might agree, the benefits of this aid have not stretched to the whole society.

\footnotetext{
${ }^{22}$ Ministry of Industries of Sri Lanka (1989); Ministry of Industrial Development of Sri Lanka (1995); Wignaraja G. (1998)

${ }^{23}$ Tolkien (1954, p.255)
} 
Although one of the "explicit aims" of the Pakistan Perspective Plan for the period 1965-85 was "elimination of dependence on foreign assistance," foreign assistance increased substantially. This, however, does not seem to lead to socio-economic development. For example, during the 1960s and 1970s, when Pakistan was the largest aid recipient among Asian countries, the average percentage of population living under poverty declined only marginally from 43\% to around 39\% (see, Pakistan Economic Survey, 199798). This foreign aid also could not induce the government to improve the education standards of the country. Although the country received huge foreign aid inflows during the 1960s and 1970s, the illiteracy rate in Pakistan remained almost unchanged (around 59-65\%) in the last three decades. In contrast, other Asian countries, like Malaysia or Sri Lanka that received only US\$2.4 and US\$3.9 per head of aid in 1970, respectively (compared with US\$7 per head of Pakistan), were able to improve the literacy rates significantly (see Table 4.2). Other social indicators, like health, employment and so on, present the same picture. Econometric studies also suggest that aid has not had any positive influence on economic growth. For example, Khan (1997) finds a negative causal effect of aid on GDP and a statistically robust negative impact of aid on economic growth. Besides the ambiguous impacts of foreign aid on the development process, aid agencies and donor countries have assumed a more eminent position in the policy configuration and have left the GOP with little liberty to formulate its own policy framework.

To sum up, it could be argued that the huge inflows of foreign capital in the shape of foreign aid have not been utilised for the development of the economy. Rather, this aid has served the vested interest of a small group of individuals and has "delayed the day of reckoning". Furthermore, the increase in loan-type aid during the 1990s has exacerbated the foreign debt problem of the country.

\section{Foreign Portfolio Investment}

Whether FPI contributes to the process of economic growth and development of a country depends on the configuration of the domestic financial system and the importance of different financial institutions in providing funds and reducing information asymmetries. In a monetary production economy, availability of money is vital for an entrepreneur when he/she decides to invest in capital goods for future production. This money could be generated either from previous profits (retained earnings) or could be raised from external sources by issuing debt/equity in the security market or borrowing from banks. The importance of the security market of a country in providing funds depends on the effectiveness of 
different types of the financial system, which, in turn, largely depends on its socio-economic structure. For example, the economic growth of Japan and Germany has been largely dependent on the bank-based financial system, while that of the US relies heavily on the security market-based system (see, for example, Levine et al., 1997). This paper follows the postKeynesian economic framework that suggests that no universal financial policy is suitable for all countries at all times. ${ }^{24}$ It implies that if the stock market (and FPI) is vital for the US, then it does not necessarily mean that it is also vital for the Pakistani economy. It is argued here that FPI can only have significant positive impacts on the process of economic growth if the socio-economic structure of a country allows the security market to perform its functions effectively, i.e. to provide funds to entrepreneurs and reduce information asymmetries. In the case of Pakistan, where the security market is not very important and not well developed, FPI has not played, and is not expected to play a vital role in economic growth and development unless the overall socio-economic environment is adjusted appropriately.

The first stock exchange of Pakistan, i.e. Karachi Stock Exchange, came into existence in September 1947..$^{25}$ Although it was developed gradually afterwards, the security market has played a relatively minor role in the industrialisation process in Pakistan. This could be attributed to the guided industrialisation polices of the GOP, particularly during the 1950s and 1960s. The government did not pay much attention to developing the stock market because it was relatively difficult to influence this financial market and its development could undermine the industrialisation policies of the authorities. Banks, by contrast, are much easier to influence and the GOP, with its interventionist policies, has utilised the bank-based system to pursue its guided industrialisation policies. The stock market in Pakistan has provided meagre funds for capital formation. For example, "on average, between 1980-90, only 5 to 6 percent of private funds have been mobilised through the stock market, and even in the 1990s, the average amount raised through new issues was only Rs 7 to 9 billion, compared to Rs 75 to 80 billion from deposit mobilisation by the commercial banking system alone (Khan, 1999, pp.231-2)”. During the 1990s, when the authorities started following liberalisation policies, huge FPI entered Pakistani stock exchanges especially through the Commonwealth Equity Fund, the Pakistan Fund, and the Credit Lyonnais Pakistan Growth Fund. After reaching its peak level and making sufficient capital gains, foreign portfolio investors pulled out of the Pakistani stock market. Due to the

\footnotetext{
${ }^{24}$ See Arestis (1992) for an excellent review of Post-Keynesian economics.

${ }^{25}$ See Husain and Qasim (1997) for a brief review of history of Pakistani stock markets.
} 
underdevelopment of the overall financial system, ${ }^{26}$ the lack of liquidity in the security market, and the presence of enormous information asymmetries, the participation of the general public in the stock market is negligible as most of the people hold bank deposits or Government's saving schemes as a preferred means of store of value.

For the last five decades, Pakistan has not had a stable democratic government. Even in the coming future, growing suspicions regarding Presidential Referendum and the shape of future governments, coupled with the American war against terrorism (possibly against Iran), has substantiated the uncertainties in the Pakistani market. This political instability has created huge uncertainties not only in the minds of foreign investors but also in the minds of the local public. The benefits of FPI depend on the economic and political environment of the host country. In the case of Pakistan, the environment has been highly unstable and, therefore, it is unlikely to have benefits from the security market in general, and FPI in particular. Given the uncertainties in Pakistan's economic environment and short-term commitment of portfolio investors, firms that seek stable sources of external funds rely on internal finance or borrow from banks. Also, due to a lack of public participation in the stock market, the benefits of FPI, if any, would go to a small group of individuals. This, however, does not imply that the stock market is completely unimportant for the development process of Pakistan. These markets are "compensating" institutions, ${ }^{27}$ to benefit from the stock market (especially from FPI), however the GOP needs to attract domestic investors to create depth and liquidity in the market, before it starts marketing the Pakistani security market to foreign investors. In other words, before attempting to attract foreign investors, GOP needs to promote the security market to the Pakistani public.

\section{Foreign Direct Investment}

The theoretical and empirical literature on the contributions of FDI to the economic growth of host countries suggests that such effects are neither automatic nor analogous in all host countries. In some countries inward FDI may contribute to the growth of host economies; in others it may not, or it may even have negative consequences. Several cross-country comparative analyses suggest that to gain from inward FDI, there are certain prerequisites that host economies must possess, for example, a certain level of economic development (Blomstrom et al., 1994), a minimum threshold stock of human capital (Borensztein et al., 1998; Hermes and Lensink, 2000), some level of

\footnotetext{
${ }^{26}$ See, however, Haque (1997) for financial system reforms in Pakistan.

${ }^{27}$ See Studart (1995)
} 
domestic financial system (Hermes and Lensink, 2000) and an outward-oriented trade policy (Bhagwati, 1978; Balasubmaranyam et al., 1999). Host countries receive different benefits also because they receive different types of FDI (Dutt, 1997). In order to evaluate the impacts of inward FDI on the economic performance of Pakistan, first we examine whether the Pakistani economy is able to benefit from inward FDI, i.e. whether it meets the above-mentioned prerequisites for FDI to contribute to its economic growth. Secondly, we discuss whether the industry pattern of FDI inflows is favourable to the economic growth of Pakistan. We then evaluate the impacts of inward FDI on the economic performance of Pakistan in the last two decades.

Borensztein et al. (1998) find that FDI will contribute to economic growth if a country has a male population above 25 years with an average of half a year $(0.52)$ of secondary schooling, i.e. a sufficient absorptive capability of the advanced technologies is available. Pakistan possessed this threshold level in $1980,{ }^{28}$ with a male population with an average of more than one year (1.146) of secondary schooling. According to another study by Hermes and Lensink (2000), the secondary enrolment rate of $12.8 \%$ in Pakistan in 1970 also satisfies the minimum human capital threshold of $8.5 \%$ for FDI to have positive impacts on economic growth. Does this mean that Pakistan has sufficient capacity in terms of human capital to benefit from inward FDI? If so, has FDI contributed to the economic growth in Pakistan? The measurement on secondary schooling used in the study of Borensztein et al. (1998) and Hermes and Lensink (2000) may not reveal the quality of education. For instance one year of secondary education in Pakistan is expected to be different from that in the UK or even in India. According to the above mentioned indicator, and the available data, there is little difference between the human capital of Pakistan and that of the UK in 1980 - Pakistan has a male population above 25 years with average of 1.146 years of secondary schooling and the UK has only 1.994 years! Table 6.1 compares the rate of secondary school enrolment, a proxy for human capital, in Pakistan with that in other Asian countries.

\footnotetext{
${ }^{28}$ The data on school attainment is from Barro and Lee (1993) and on enrolment is from World Development Indicators 2001
} 
Table 6.1: Secondary School Enrolment in selected Asian countries (\% of Gross)

\begin{tabular}{llll}
\hline Country & $\mathbf{1 9 7 0}$ & $\mathbf{1 9 8 0}$ & $\mathbf{1 9 9 0}$ \\
\hline Pakistan & $\mathbf{1 2 . 8}$ & $\mathbf{1 4 . 2}$ & $\mathbf{2 2 . 7}$ \\
Bangladesh & N/A & 17.5 & 19 \\
Hong Kong & 35.8 & 64.1 & 79.6 \\
Indonesia & 16.1 & 29 & 44 \\
India & 24.2 & 29.9 & 44.4 \\
S. Korea & 41.6 & 78.1 & 89.8 \\
Malaysia & 34.2 & 47.7 & 56.3 \\
Mauritius & 30.7 & 50 & 52.9 \\
Singapore & 46 & 59.9 & 68.1 \\
Sri Lanka & 47 & 54.6 & 73.8 \\
\hline
\end{tabular}

Source: World Development Indicators 2001

The findings suggest that different aspects of education, which are of paramount importance for a country to gain from inward FDI, have not improved in Pakistan during the last three decades.

Pakistan also satisfies the criterion suggested in Hermes and Lensink's (2000) study that the domestic financial market should reach a certain level of development for inward FDI to contribute to economic growth. Since 1964, the private sector credit to GDP ratio, a measure for financial market development, of Pakistan has always been above $23 \%$, i.e. much higher than the minimum threshold of $12 \%$ found in Hermes and Lensink's study. Given the high cost of financial intermediation and huge non-performing loans, this indicator does not imply that the financial sector in Pakistan is well developed. The inefficiency of the domestic financial market has obstructed inward FDI to contribute to the economic growth of Pakistan. One of the most crucial (and most difficult to attain) impacts of inward FDI that can lead to sustainable economic growth is technology spillovers to domestic firms, especially through linkages with foreign firms. In the case of Pakistan, it could be argued that the inefficient financial sector has deterred local firms from upgrading, imitating or adopting new technologies to compete and/or become local suppliers for foreign firms. The reform of the financial market as well as the government's support may eventually improve the indigenous technological capacity and build up a sound domestic entrepreneurial environment.

According to the studies of Bhagwati (1978) and Balasubramanyam et al. (1999), inward FDI would exert no significant influence upon the growth 
of Pakistan because this country follows an inward-oriented trade strategy, not an outward-oriented strategy. ${ }^{29}$ The adoption of an inward-oriented strategy creates inefficiencies and prevents the country from providing a sound economic climate to get benefits from inward FDI. Also unlike Sri Lanka and India, which have already embarked on promoting linkages between domestic and foreign firms, Pakistan has not yet actively initiated any policy measures in this regard.

The previous discussion shows that Pakistan has not yet equipped itself sufficiently to benefit from inward FDI, and thus the impacts of FDI inflows on the economic performance could be expected to be rather modest. The limited contribution of FDI to economic growth may also result from the pattern of FDI inflows. Dutt (1997) argues that the sectoral pattern of FDI is also an important determinant for the growth consequences of inward FDI. Following this theme we can see that the positive impacts of inward FDI is insignificant because FDI projects do not flow to sectors, such as textiles, electronics and machinery, which could enhance technology level and exports. The patterns of FDI inflows are, however, partly dependent on the country's technological capacity. When Pakistan lacks a skilled labour force, it is unlikely to host skill-intensive FDI projects. The same argument may be applied to the linkages between foreign and domestic firms. When domestic firms are unable to become suppliers for foreign firms, it is unrealistic to expect FDI to create backward linkages and technology spillovers. Also, the labour productivity in Pakistan, measured by manufacturing value added (MVA) per worker, is much lower than those of other Asian countries and similar to that of Sri Lanka. For example, in 1997 the products that an average Pakistani worker produced in the manufacturing sector was worth around US\$ 2584, while an Indian could produce US\$ 9564, a Malaysian US\$ 14823 and a Singaporean US\$ 58039 (Table 6.2). The proposition that the significant increase in FDI inflows in the 1990s could improve the technological level and thus enhance the economic growth rate is rejected because the labour productivity of the 1990 s has not improved significantly from that of the 1980s. The average levels of MVA per worker in the 1980s and 1990s are US\$ 1439 and 2475, respectively.

\footnotetext{
${ }^{29}$ The ranking in Balasubramanyam et al. (1999) study is based on the World Bank Classification of Countries and the CUSUMSQ test.
} 
Table 6.2 Manufacturing Value Added per worker in selected Asian countries (in constant 1995 US\$)

\begin{tabular}{lccccccc}
\hline & Pakistan & India & \multicolumn{2}{c}{ Sri Lanka Indonesia } & Malaysia & \multicolumn{2}{c}{ Singapore Thailand } \\
\hline 1982 & 1066 & 3655 & N/A & 1687 & 8424 & 24547 & 5436 \\
1983 & 1232 & 4065 & N/A & 2481 & 8909 & 26139 & 6088 \\
1984 & 1296 & 4318 & N/A & 2920 & 9660 & 28281 & 6471 \\
1985 & 1371 & 4452 & 1336 & 2954 & 9171 & 28756 & 6125 \\
1986 & 1528 & 4784 & 1330 & 3338 & 9804 & 31539 & 6670 \\
1987 & 1462 & 5134 & N/A & 3557 & 10382 & 31683 & 7301 \\
1988 & 1758 & 5596 & N/A & 3865 & 11100 & 33379 & 8530 \\
1989 & 1793 & 6167 & N/A & 3516 & 10965 & 34421 & 8793 \\
1990 & 1846 & 6550 & 1792 & 3753 & 11146 & 34007 & 8992 \\
1991 & 2099 & 6214 & 1705 & 4018 & 11512 & 37332 & 9084 \\
1992 & 2194 & 6500 & 2144 & 4482 & 11409 & 37788 & 9731 \\
1993 & 2531 & 7043 & 2252 & 4460 & 12119 & 41871 & 9835 \\
1994 & 2831 & 7728 & 2222 & 4061 & 12799 & 48011 & 11059 \\
1995 & 2825 & 8455 & 2327 & 4816 & 13512 & 54082 & 10820 \\
1996 & 2890 & 9103 & 2421 & 5056 & 14284 & 56603 & 11686 \\
1997 & 2584 & 9564 & 2316 & 5111 & 14823 & 58039 & 12101 \\
\hline
\end{tabular}

Source: Data compiled from World Development Indicators 2001 and ADB Key Indicators: Growth and Change in Asia and the Pacific 2001

This brief analysis suggests that FDI inflows have not contributed much to the process of economic growth and development in Pakistan because its inadequate level of human capital and domestic entrepreneur capability has neither enabled Pakistan to benefit from inward FDI nor attracted the type of FDI that could possibly contribute to the economy.

\section{Conclusion}

This paper reviews the trends of two types of foreign capital inflows, namely foreign aid and foreign private investment, to Pakistan. It suggests that, like other developing countries, the volume of foreign aid to Pakistan has been decreasing. Also the aid agencies and donor countries have assumed an eminent position in dictating the policies and left the GOP with little autonomy. A comparison with other Asian countries suggests that Pakistan has been quite unsuccessful in attracting foreign investors. The slow growth rate of foreign private investment, including FDI and FPI, could be attributed to the inconsistencies in successive government's policies and poor socio-economic infrastructure. The policies pursued by the GOP lay too much stress on financial and fiscal incentives, while the development of 
domestic infrastructure, human capital, and institutional structure has been undermined. The problem has been exacerbated due to high political instability in Pakistan.

Given the amount of foreign capital that it has attracted, Pakistan has not been able to reap the benefits of such inflows. The impact of foreign aid is negligible. Also, foreign private investment, especially FDI, has a minimal impact on the Pakistani economy due to lack of sufficient human capital, domestic enterprises development and institutional framework, and the absence of linkages between foreign and domestic firms. To gain from foreign private investment, authorities need to concentrate on the development of human capital and domestic entrepreneurs. Although this paper provides some insights on the impact of foreign capital on the economic performance of Pakistan, more research is required in this area, and economic researchers are called upon for further research on the role of foreign capital inflows, especially on the linkages between foreign and domestic firms, the influence of foreign firms on the human capital development in Pakistan, and on the influence of foreign investment on the domestic financial system. 


\section{References}

Akhtar, M. H., 2000, "The Determinants of Foreign Direct Investment in Pakistan: An Econometric Analysis”, The Lahore Journal or Economics, Vol. 5(2), pp.1-22.

Arestis, P., 1992, The post-Keynesian approach to economics: an alternative analysis of economic theory and policy, Aldershot: Elgar.

Balasubramanyam V. N., M. Salisu and D. Sapsford, 1999, "Foreign Direct Investment as an Engine of Growth", The Journal of International Trade and Economic Development, Vol. 8(1), pp. 27-40.

Bhagwati, J. N., 1978, Anatomy and Consequences of Exchange Control Regimes, Vol. 1, Studies in International Economic Relations, No. 10, New York, National Bureau of Economic Research.

Blomstrom, M. and A. Kokko, 1996, The Impacts of Foreign Investment Host Countries: A Review of the Empirical Evidence, Stockholm School of Economics, mimeo.

Blomstrom, M., R. E. Lipsey and M. Zejan, 1994, "What explains the growth of Developing Countries?" in Convergence of productivity: Crossnational studies and historical evidence, edited by Baumol, W. J., R. R. Nelson and E. N. Wolff, Oxford University Press, New York.

Borensztein, E., J. De Gregorio and J-W Lee, 1998, "How does Foreign Direct Investment affect Economic Growth?”, Journal of International Economics, Vo1. 45(1), pp. 115-135.

Bornschier, V., C. Dunn and R. Rubinson, 1987, "Cross-national evidence of the effects of foreign investment and aid on economic growth and inequality", American Journal of Sociology, Vol. 84(3), pp. 651-683.

Buckley, P. J., 2000, "Motives of Foreign Firms in Pakistan", The Lahore Journal of Economics, Vol. 5(2), pp.87-106.

Casella, A. and Eichengreen, B., 1996, "Can Foreign Aid Accelerate Stabilisation?”, The Economic Journal, Vo1. 106(436), p. 605-619.

Chia, Y. S., 1999, "Trade, foreign direct investment and economic development of Southeast Asia”, Pacific Review, Vol. 12(2) pp 249-270. 
Dutt, A. K., 1997, "The pattern of direct foreign investment and economic growth", World Development, Vol. 25(11), pp.1925-1936.

Eberstadt, N., 1992, "Wrongheaded Aid to Russia", Wall Street Journal, $1^{\text {st }}$ Sep., P.A14.

Global Development Finance, 2000, World Bank, Washington DC.

Grabe1, I., 1996, "Marketing the Third World: The contradictions of portfolio investment in the global economy", World Development, Vol. 24(11), pp. 1761-1776

Griffin, K., 1991, "Foreign Aid after the Cold War", Development and Change, Vol. 22(4), pp.645-685.

Haque, Nadeem U1, 1997, "Financial Market Reform in Pakistan", Pakistan Development Review, Vo1. 36(4), pp. 839-854.

Hausmann, R. and E. Fernandez-Arias, 2000, Foreign Direct Investment: Good Cholesterol? Inter-American Development Bank, Working paper no. 417.

Hermes, N and R. Lensink, 2000, Foreign Direct Investment, Financial Development and Economic Growth, University of Groningen, mimeo.

Husain, I., 1999, Pakistan: The Economy of an Elitist State, Oxford University Press.

Husain, F and M. A. Qasim, 1997, "The Pakistani Equity Market in 50 Years: A Review”, Pakistan Development Review, Vol. 36 (4), pp. 863-872.

Khan, Z. M., 1996, "Pakistan: Prospects for Private Capital Flows and Financial Sector Development”, Pakistan Development Review, Vol. 35 (4), pp.853-883.

Khan, S. R., 1997, "Has Aid Helped in Pakistan?", Pakistan Development Review, Vo1. 36 (4), pp.947-957.

Khan, S. R., 1999, Fifty Years of Pakistan's Economy: Traditional Topics and Contemporary Concerns, Oxford University Press.

Levine, R., 1997, "Financial Development and Economic Growth: Views and Agenda”, Journal of Economic Literature, Vo1. 35 (2), pp. 688-726. 
Loree, D. W. and S. E. Guisinger, 1995, "Policy and Non-Policy Determinants of US Equity Foreign Direct Investment" Journal of International Business Studies Vol. 26 (2), pp 281-299.

Lucas, 1993, "On the Determinants of FDI: "Evidence from East and Southeast Asia”, World Development, Vo1. 21(3), pp. 391-406.

MacDougall, G. D. A., 1960, "The Benefits and Costs of Private Investment from Abroad: A Theoretical Approach”, Economic Record, Vol. 27, pp. 13-35.

Ministry of Industries of Sri Lanka, 1989, A Strategy for Industrialization in Sri Lanka, MOI, Colombo.

Ministry of Industrial Development of Sri Lanka, 1995, New Industrialization Strategy for Sri Lanka, Sridevi Printers, Colombo.

Mishkin, FS, 1999, "Lessons from the Asian crisis", Journal of International Monetary and Finance, Vo1. 18 (4), pp. 709-723.

Oman, C., 2000, Policy Competition for Foreign Direct Investment, OECD Development Center.

Papanek, Gustav F., 1967, Pakistan's Development: Social Goals and Private, Cambridge, Mass.: Harvard University Press.

Pirsig, R. M., 1976, Zen and the art of motorcycle maintenance: an inquiry into values, London: Bodley Head.

Rana, P. B. and J. M. Dowling, 1988, "The Impact of Foreign Capital on Growth: Evidence from Asian Developing Countries”, The Journal of Developing Economies, Vol. 26(1), pp. 3-11.

Root, F. and A. Ahmed, 1979, "Empirical Determinants of Manufacturing Direct Foreign Investment in Developing Countries”, Economic Development and Cultural Change, Vol. 27(4) pp. 751-767.

Ruffin, R. J., 1993, "The Role of Foreign Investment in the Economic Growth of the Asian and Pacific Region”, Asian Development Review, Vol. 11(1), pp. 1-23.

Sachs, J., 1994, “Betrayal”, New Republic, Vo1. 31, p.14-18. 
Saggi, K., 2000, Trade, Foreign Direct Investment, and International Technology Transfer: A Survey, World Bank Working Paper No. 2349.

Studart, R., 1995, Investment Finance in Economic Development, London: Routledge.

Todaro, M. P., 1992, Economics for a Developing World: An Introduction to Principles, Problems and Policies for Development, London: Longman $3^{\text {rd }}$ ed.

Tolkien, J. R. R. 1954 The Lord of the Rings, London: Allen \& Unwin

Wignaraja G., 1998, Trade Liberalisation in Sri Lanka: Exports, Technology and Industrial Policy, London: Macmillan.

World Development Indicators CD-ROM, 2001.

World Investment Report, 1992: Transnational Corporations and Integrated International Production, United Nations publication, United Nations, New York and Geneva.

World Investment Report, 1997: Transnational Corporations, Market Structure and Competition Policy United Nations publication, United Nations, New York and Geneva.

World Investment Report, 2001: Promoting Linkages United Nations publication, United Nations, New York and Geneva.

World Institute for Development Economics Research (WIDER), 1990, Foreign portfolio Investment in Emerging Markets, WIDER Study Group Series.

Zaidi, S. A., 1999, Issues in Pakistan’s Economy, Oxford University Press.

Zhan, J. X. and T. Ozawa, 2001, Business restructuring in Asia: Crossborder $M \& A s$ in the crisis period, Copenhagen Business School Press, Copenhagen. 